\title{
Clinical Features of Cases Followed with Idiopathic Hypercalciuria in Childhood, Long-term Follow-up Results and Retrospective Evaluation of Complications
}

\author{
Çocukluk Çağında Idiyopatik Hiperkalsiüri ile İzlenen \\ Olguların Klinik Özellikleri, Uzun Dönem Takip Sonuçları ve \\ Komplikasyonların Retrospektif Incelenmesi
}

(1) Alper Köker ${ }^{1}$, (1) Meral Torun Bayram², (1) Alper Soylu², (1) Derya Özmen², (1) Salih Kavukçu², (1) Mehmet Atilla Türkmen²

${ }^{1}$ Dokuz Eylül University Faculty of Medicine, Department of Pediatrics, İzmir, Turkey

${ }^{2}$ Dokuz Eylül University Faculty of Medicine, Department of Pediatric Nephrology, İzmir, Turkey

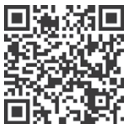

Keywords

Idiopathic hypercalciuria, children, followup, complications

Anahtar Kelimeler

İdiyopatik hiperkalsiüri, çocuk, izlem, komplikasyonlar

Received/Geliş Tarihi : 15.07.2019

Accepted/Kabul Tarihi : 21.08.2019

doi:10.4274/meandros.galenos.2019.41713

Address for Correspondence/Yazışma Adresi: Alper Köker MD,

Dokuz Eylül University Faculty of Medicine, Department of Pediatrics, İzmir, Turkey

Phone : +90 5054790149

E-mail : kokeralper@gmail.com

ORCID ID: orcid.org/0000-0003-1231-3023

(C) Meandros Medical and Dental Journal, Published by Galenos Publishing House.

This is article distributed under the terms of the

Creative Commons Attribution NonCommercial 4.0

International Licence (CC BY-NC 4.0).

\section{Abstract}

Objective: The objective of this study is to assess clinical, laboratory and imaging findings, treatment styles and long-term outcomes of paediatric patients followed with idiopathic hypercalciuria (IH).

Materials and Methods: We retrospectively evaluated and reviewed the files of patients aged between 3 months and 18 years with respect to age at the time of diagnosis, gender, admission complaints, follow-up period, laboratory and imaging findings (routine urinary analysis, blood and urinary biochemistry, parathormone, vitamin D level, urinary system ultrasonography and bone mineral density), onset and follow-up anthropometric data and complications.

Results: The average ages of male and female patients (total: 52) diagnosed with $\mathrm{IH}$ were 30 and 22 years, respectively. The follow-up periods of male and female patients were $44.5 \pm 40.8$ and $22.5 \pm 3.2$ (6-96) months. The most frequent admission complaints were abdominal pain and underlying urinary tract infection (UTI) and history of haematuria. The average calcium level at the time of admission was $6.56 \pm 2.65 \mathrm{mg} / \mathrm{kg} / \mathrm{day}$, and the average calcium/creatinine level was $0.85 \pm 0.68$ $\mathrm{mg} / \mathrm{mg}$. Kidney stones were determined in 41 (79\%) patients. In total, $21(40 \%)$ patients had UTI. During follow-up, UTI developed in 6 (11.5\%) of them. Following medical treatment and/or nutrition recommendations, there was a reduction in the frequency of UTI rate, haematuria and enuresis ( $10 / 11$ vs $6 / 25, p=0.030 ; 8 / 8$ vs $3 / 33$, $\mathrm{p}=0.001$; and vs $1 / 46, \mathrm{p}<0.001$, respectively).

Conclusion: Children with $\mathrm{IH}$ can apply with different clinical pictures and their conditions can lead to complications such as kidney stones, UTI. However, hypercalciuria, clinical complaints and complications can regress thanks to medical treatment or nutrition recommendations.

Öz

Amaç: Bu çalışmada idiyopatik hiperkalsiüri (iH) tanısı ile izlenen çocuk hastaların klinik, laboratuvar, görüntüleme bulgularının, tedavi şekillerinin ve uzun süreli sonuçlarının değerlendirilmesi amaçlanmıştır. 
Gereç ve Yöntemler: IH'li 3 ay-18 yaş arasındaki hastaların dosyaları retrospektif olarak; tanı anındaki yaş, cinsiyet, başvuru şikayeti, izlem süresi, laboratuvar ve görüntüleme bulguları (rutin idrar analizi, kan ve idrar biyokimyası, paratiroid hormon, D vitamini düzeyi, üriner sistem ultrasonografisi ve kemik mineral yoğunluğu), başlangıç ve izlemdeki antropometrik veriler ve komplikasyonlar açısından değerlendirildi.

Bulgular: IH tanısı alan 52 hastanın (Erkek/Kadın: 30/22) ortalama tanı yaşı ve izlem süresi $44,5 \pm 40,8$ ve $22,5 \pm 3,2$ (6-96) ay idi. En sık başvuru yakınmaları sırası ile karın ağrısı, geçirilmiş idrar yolu enfeksiyonu (iYE) ve hematüri öyküsü idi. Başvuru sırasındaki ortalama idrar kalsiyum düzeyi $6,56 \pm 2,65 \mathrm{mg} / \mathrm{kg} / \mathrm{gün}$ ve kalsiyum/kreatinin oranı da 0,85 $\pm 0,68 \mathrm{mg} / \mathrm{mg}$ idi. Hastalardan 41 (\%79) tanesinde tanı sırasında böbrek taşı saptandı. Hastaların 21 'inde (\%40) iYE geçirme öyküsü olup 6'sında (\%11,5) izlem sırasında iYE gelişmişti. Medikal tedavi ve/veya beslenme önerileri sonrası hastalarda iYE sıklı̆ı, hematüri ve enürezis sıklıklarında azalma vardı (sırasıyla $10 / 11$ vs $6 / 25, p=0,030 ; 8 / 8$ vs $3 / 33, p=0,001,3 / 2$ vs $1 / 46, p<0,001)$.

Sonuç: ï'li çocuklar farklı klinik tablolar ile başvurabilmekte ve böbrek taşı, iYE gibi komplikasyonlara sebep olabilmektedir. Ancak medikal tedavi veya beslenme önerileri ile hiperkalsiüri, klinik yakınmalar ve komplikasyonlar gerileyebilmektedir.

\section{Introduction}

Idiopathic hypercalciuria $(\mathrm{IH})$ was first defined by Albright et al. (1) in 1953. While IH incidence is reported to be between $5-10 \%$ in adults (2), this rate changes between $2.2-6.2 \%$ in the paediatric age group (3). IH is a condition characterized by immoderate calcium excretion in urine despite normal or limited calcium intake without any underlying cause such as immobility, diuretic use, renal tubular acidosis, Paget's disease, malignancies, hyperthyroid, sarcoidosis, or glucocorticoid increase that may give rise to hypercalciuria in conjunction with normal serum calcium, phosphorus, parathormone (PTH) and vitamin D levels $(4,5)$.

Calcium excretion is dependent on glomerular filtration and tubular reabsorption. In normal conditions, the amount of calcium excreted changes depending on calcium resorption and intestinal absorption rate (6). IH is attributed to a defect in renal tubular reabsorption (renal hypercalciuria) or increased absorption from the gastrointestinal system (absorptive hypercalciuria) (7). The oral calcium loading test was used to differentiate these two forms in the past. Nevertheless, the oral loading test is not frequently utilized to differentiate these two types since hypercalciuria is thought to be a spectrum of only one continuous disease of absorptive and renal forms.

$\mathrm{IH}$ is a significant metabolic risk factor in children with urinary system stones. Children with $\mathrm{IH}$ may apply to hospital with different clinical complaints; however, some of them may be asymptomatic (8$11)$. IH with renal stone can lead to complications such as reduction in bone mineral density (BMD) (5). In this study, children followed-up with IH diagnosis were evaluated with respect to their clinical findings, demographic characteristics, treatment methods and long-term results.

\section{Materials and Methods}

Patients followed-up with $\mathrm{IH}$ diagnosis at Dokuz Eylül University Medicine Faculty Paediatric Nephrology Clinic were included in the study. The files of all patients were retrospectively reviewed in terms of their admission ages, anthropometric data, gender, family histories, clinic admission complaints, laboratory findings, treatment methods, follow-up periods, disease progression and complications.

\section{Ethical Approval}

The study protocol was designed in compliance with the Declaration of Helsinki. Informed consent was obtained from parents or legal guardians before enrollment in the study. The study was begun after receiving the approval of the Ethics Committee of the Dokuz Eylül University (decision no: 2013/17-05, date: 02/05/2013).

\section{Patient Selection}

Patients whose serum calcium, phosphorus, PTH, and vitamin $D$ levels were normal; however, with calcium/creatinine $(\mathrm{mg} / \mathrm{mg})$ rate $0.8 \mathrm{mg} / \mathrm{mg}$ for 0-12 months old, $0.53 \mathrm{mg} / \mathrm{mg}$ for $1-3$ years old, 0.4 $\mathrm{mg} / \mathrm{mg}$ for $3-5$ years old, $0.3 \mathrm{mg} / \mathrm{mg}$ for $5-7$ years old and $0.21 \mathrm{mg} / \mathrm{mg}$ for over 7 years old or calcium excretion of over $4 \mathrm{mg} / \mathrm{kg} /$ day in urine collected in 24 hours (h) were included in the study (3). Those with immobilization, renal tubular acidosis and other diseases causing tubulopathy, hypercalcemia, malignancy, hyperparathyroidism, hyperthyroidism, elevation in vitamin D level, diuretic or steroid treatment use history were excluded from the study. 


\section{Clinical, Laboratory and Imaging Findings}

Gender, admission age, follow-up duration, consanguinity and stone history, admission complaints, height and weight percentile values at the first and last control, urea at the outset and during follow-up, creatinine, serum electrolyte, alkaline phosphatase, PTH and $25 \mathrm{OH}$ vitamin D levels, fasting random calcium/creatinine ratio on the second morning voided urine sample (in patients with urinary incontinence/enuresis or infants) or $24 \mathrm{~h}$ urine calcium measurement, urinary system ultrasonography findings and complications of the patients were recorded.

\section{Statistical Evaluation}

While the evidence obtained from the study were assessed, the SPSS (Statistical Package for Social Sciences) for Windows 15.0 programme was utilized for statistical analyses. In the analysis, the $t$ test was used for continuous variables and chi-square test was employed in the comparison of variables of both independent and dependent groups (McNemar test). In addition, Pearson correlation analysis was used to determine the relationship between numerical variables. Statistical significance level was accepted as $p<0.05$.

\section{Results}

\section{Demographic Findings}

In the study, there were a total of 52 patients including $30(57.7 \%)$ boys and $22(42.3 \%)$ girls. The average diagnosis age and follow-up period were $44.5 \pm 40.8$ (3-196) and 22.5 \pm 3.2 (6-96) months, respectively. There was consanguinity history between mother and father in $5(9.6 \%)$ patients and renal stone history in the family of 33 (63\%). Of these, 22 (67\%) were mother-father, 10 (30\%) were grandmothergrandfather and 1 (3\%) was a cousin. BMD was evaluated in only 3 out of 52 patients involved in the study and it was normal.

\section{Clinical Findings}

The most common complaints in patients with IH were abdominal pain, urinary tract infection (UTI) and haematuria (Table 1). At the time of admission, abdominal pain was present in $21(40.4 \%)$ patients. Nephrolithiasis was present in 18 (86\%) patients. In 3 patients, there was abdominal pain complaint without stone. Abdominal pain rate was higher in those with nephrolithiasis $(18 / 23$ vs $3 / 8, p=0.034)$. In
7 (52\%) patients, UTI history was known. There was UTI in 21 (40\%) patients at the time of admission and UTI developed in 6 (11.5\%) during follow-up. The UTI rate was higher in patients with nephrolithiasis at the time of first admission ( $18 / 23$ vs $3 / 8, p=0.034$ ). Nevertheless, there was no nephrolithiasis in 5 out of 6 patients who developed UTI later and UTI was observed during follow-up. Dimercaptosuccinic acid (DMSA) was taken for 23 patients with UTI history and renal scar was determined in 13 (57\%) patients. Eight patients with renal scar had voiding cystourethrography performed. None of the patients had vesicourethral reflux detected. Haematuria was present in 16 patients with $\mathrm{IH}$ and it was macroscopic haematuria in 8 (50\%). The haematuria rate was not different initially in patients with nephrolithiasis $(12 / 29$ vs $4 / 8, p=0.663)$. In addition, $4(50 \%)$ patients with macroscopic haematuria developed macroscopic haematuria without nephrolithiasis or UTI. Enuresis complaint was present in $5(9.6 \%)$ patients ( 2 were non-monosymptomatic) and it regressed with only $\mathrm{IH}$ treatment in 2 patients. There was incontinence in $3(5.7 \%)$ patients. In addition, secondary enuresis developed in one patient during follow-up.

Forty-one (78.8\%) patients had nephrolithiasis and it was observed that these stones continued to be present in 29 (70\%) throughout follow-up. Moreover, 3 patients who did not have it at the outset developed stones.

Body weight and height percentiles of patients are given in Table 2 and 3. The body weight of 7 (13.5\%) patients with $\mathrm{IH}$ was $<3$ percentile at the time of first admission. In six of these seven patients, body weight percentiles were $>3$ percentile at the last follow-up. Patient numbers with body weight $<3$ percentile were

\begin{tabular}{|l|l|}
\hline $\begin{array}{l}\text { Table 1. Admission complaints of children with } \\
\text { idiopathic hypercalciuria }\end{array}$ \\
\hline Admission complaint & Number (percent) $\mathbf{n}(\%)$ \\
\hline Abdominal pain & $21(40.4)$ \\
\hline Urinary system infection & $21(40.4)$ \\
\hline Hematuria & $16(30.8)$ \\
\hline Vomiting & $12(23.1)$ \\
\hline Insufficiency in weight gain & $7(13.5)$ \\
\hline Enuresis & $5(9.6)$ \\
\hline Others & $11(21.1)$ \\
\hline
\end{tabular}


different at the time of first admission and last control ( $7 / 45$ vs $1 / 51, p=0.033$ ).

While 24 patients (46.2\%) were advised to use a low salt diet and nutrition without any medical treatment, $10(19.2 \%)$ patients had hydrochlorothiazide administered, 2 (3.8\%) were given potassium-magnesium citrate, 11 (21\%) had potassium citrate administered and $5(9.6 \%)$ were given both hydrochlorothiazide and potassium citrate. After medical treatment, there was a reduction in UTI, haematuria and enuresis rates in patients (respectively, $10 / 11$ vs $6 / 25, p=0.030 ; 8 / 8$ vs $3 / 33$, $\mathrm{p}=0.001,3 / 2$ vs $1 / 46, \mathrm{p}<0.001$ ).

\section{Laboratory Findings}

The average calcium level in urine was identified as $6.56 \pm 2.65(4.05-13.70) \mathrm{mg} / \mathrm{kg} /$ day in $24 \mathrm{~h}$ urine and it was $0.85(0.22-3.0) \mathrm{mg} / \mathrm{mg}$ in spot urinary workup.
There was haematuria in urinary microscopy of 16 (31\%) patients at the time of diagnosis and pyuria in $14(27 \%)$. During follow-up, pyuria continued in 10 (19\%) patients, nonetheless, there was no stone and/ or UTI in these patients. Haematuria progressed in 7 $(13 \%)$ patients and in five of them, UTI and/or renal stone were present. The haematuria rate was not different in patients with and without stone (12/29 vs $4 / 7, p=0.455)$. Pyuria rate was not different between patients with and without UTI (7/14 vs 7/24, $p=0.391)$. Renal stone was present in $6(25 \%)$ out of 24 patients with UTI but no pyuria.

Calcium levels in $24 \mathrm{~h}$ urine and calcium/creatinine rate in spot urine measured during at the time of admission and last controls were different from each other and decreased gradually (respectively, $p=0.001$ and $p=0.021$ ) (Table 4). Nonetheless, average urine

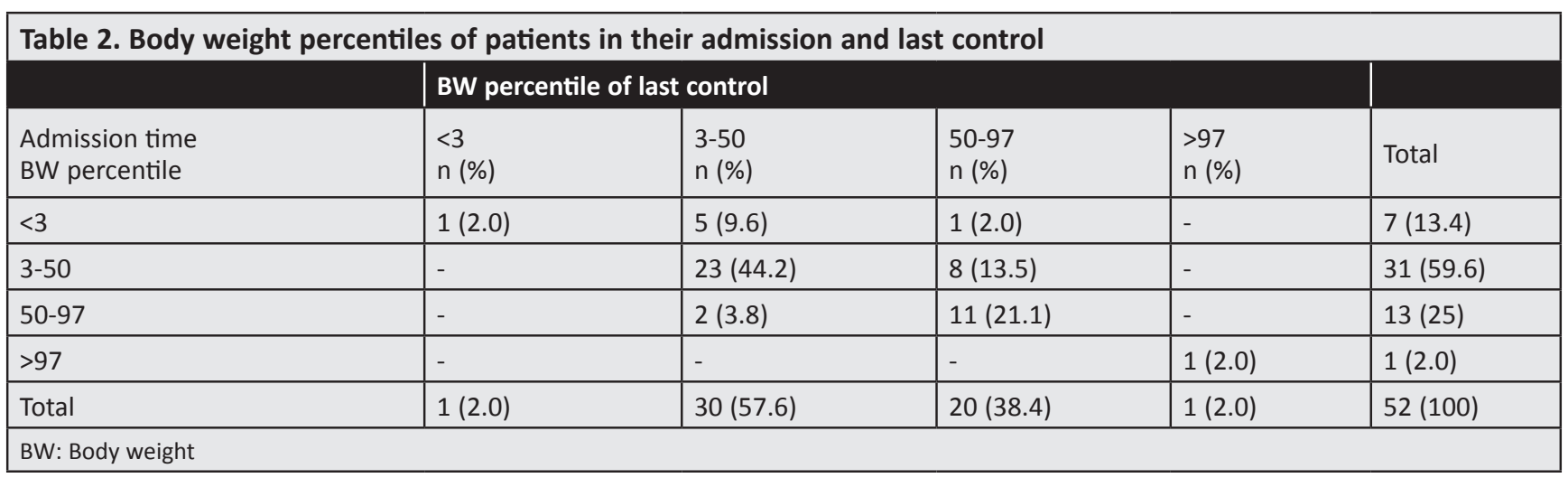

Table 3. Admission and last control height percentiles of patients

\begin{tabular}{|c|c|c|c|c|c|}
\hline \multirow[b]{2}{*}{$\begin{array}{l}\text { Admission time height } \\
\text { percentile }\end{array}$} & \multicolumn{4}{|c|}{ Last control height percentile } & \multirow[b]{2}{*}{ Total } \\
\hline & $\begin{array}{l}<3 \\
\text { n (\%) }\end{array}$ & $\begin{array}{l}\text { 3-50 } \\
\text { n (\%) }\end{array}$ & $\begin{array}{l}50-97 \\
\text { n (\%) }\end{array}$ & $\begin{array}{l}>97 \\
n(\%)\end{array}$ & \\
\hline$<3$ & - & $2(3.9)$ & $1(2.0)$ & - & $3(5.7)$ \\
\hline $3-50$ & - & $18(34.5)$ & $5(9.6)$ & - & $23(44.2)$ \\
\hline $50-97$ & - & $7(13.5)$ & $18(34.5)$ & - & $25(48.1)$ \\
\hline$>97$ & - & - & - & $1(2.0)$ & $1(2)$ \\
\hline Total & - & 27 (51.9) & $24(\% 46.1)$ & $1(2.0)$ & $52(100)$ \\
\hline
\end{tabular}

Table 4. Calcium excretion in $\mathbf{2 4}$ hour urine of patients at the time of admission, first and last control and comparison of spot urine calcium/creatinine rate

\begin{tabular}{|l|l|l|} 
& Calcium excretion in $\mathbf{2 4}$ hour urine $\mathbf{( m g / k g / d a y )}$ & Spot urine Calcium /creatinine rate (mg/mg) \\
\hline Admission & $6.55 \pm 2.76$ & $0.85 \pm 0.68$ \\
\hline First control & $5.26 \pm 3.37$ & $0.61 \pm 0.40$ \\
\hline Last control & $3.53 \pm 1.90$ & $0.50 \pm 0.26$ \\
\hline $\mathrm{p}$ & 0.001 & 0.021 \\
\hline
\end{tabular}


calcium excretion was not determined to be different before and after treatment in patients with $\mathrm{IH}$ and in those receiving and not receiving hydrochlorothiazide.

There was no statistically significant difference identified in blood urea nitrogen (BUN), creatinine, serum calcium, PTH, alkaline phosphatase (ALP), and blood gas values. However, there was a significant decrease in vitamin D level (Table 5). On the other hand, no correlation was found between vitamin $D$ reduction and urine calcium excretion in $24 \mathrm{~h}(p=0.226$ $\left.r^{2}=0.241\right)$.

\section{Discussion}

While $\mathrm{IH}$ occurs in $5 \%$ of society, this rate escalates to $22-50 \%$ in patients with urinary system stone. It is observed nearly 1.2-3 times more in males $(12,13)$. In the present study, the male/female rate was 1.3:1.

Children with IH apply to doctors with complaints such as abdominal pain, recurrent UTI, macroscopic or microscopic haematuria, urination dysfunction, and enuresis; however, a substantial number may remain asymptomatic $(11,12)$. The most common admission complaints were abdominal pain, recurrent UTI and haematuria in our patients.

Since abdominal pain is the most frequent admission complaint, association with nephrolithiasis and/or UTI is considered in patients with $\mathrm{IH}$. In the current study, there was abdominal pain in $40 \%$ of patients at the time of admission. In $86 \%$ of these patients, nephrolithiasis accompanied the disease. Nonetheless, abdominal pain was present in 3 patients without stone or UTI.

UTI history was present in almost half of patients $(52 \%)$ in the current study. When this rate is compared with the lifetime incidence of UTI, it was distinctly higher (in girls $3.3-8.4 \%$ - in boys 1.1-
1.8) (14). In a study carried out by Fallahzadeh et al. (15), it was determined that the admission rate with UTI in children diagnosed with hypercalciuria was established as $30.1 \%$. Biyikli et al. (16) determined this rate as $43 \%$. Stojanović et al. (17) stated that at least $65 \%$ of patients with hypercalciuria experienced UTI once in their lifetime. The correlation between UTI and IH was reported in other studies. It can be attributed this situation to microcrystals damaging urinary epithelium and owing to this, it can cause uroepithelium to decrease bactericidal activity and disrupt intimate contact between the epithelial cell surface gap and bacteria necessary for local IgA secretion and the initiation of antibacterial response. In addition, crystals form a reliable shield for bacteria, and they are clarified to form an obstacle for mechanical purification with urine $(18,19)$. It is also reported that UTI recurrence diminishes in those with recurrent UTI diagnosed with hypercalciuria following treatment $(9,19)$. The UTI rate also reduced in our patients.

Renal scar was identified in half of patients (57\%) who had experienced UTI and had DMSA performed. It is higher when compared to results of a study carried out in normal Turkish society (20). This situation can probably be associated with increased expression of a number of genes coding transcriptional factors as a result of interactions of calcium oxalate monohydrate crystals with epithelial cells, extracellular matrix regulators and growth factors (21).

Haematuria is the most important symptom in children with $\mathrm{IH}$. In studies, the incidence of $\mathrm{IH}$ was determined as $28-35 \%$ in patients with microscopic or macroscopic haematuria $(8,9)$. Although microscopic haematuria progresses asymptomatically in $\mathrm{IH}$, there can sometimes be dysuria and suprapubic pain with

\begin{tabular}{|c|c|c|c|c|}
\hline & $\begin{array}{l}\text { Admission } \\
\text { Average value ( } \pm S D)\end{array}$ & $\begin{array}{l}\text { First Control } \\
\text { Average value ( } \pm S D)\end{array}$ & $\begin{array}{l}\text { Last Control } \\
\text { Average value }( \pm S D)\end{array}$ & $\mathbf{p}$ \\
\hline $25 \mathrm{OH}-\mathrm{D}$ vitamin & $75.42 \pm 34.69$ & $61.42 \pm 32.39$ & $49.57 \pm 31.62$ & 0.041 \\
\hline PTH & $20.49 \pm 12.65$ & $20.90 \pm 15.04$ & $29.04 \pm 14.60$ & 0.544 \\
\hline ALP & $250.16 \pm 66.60$ & $231.16 \pm 66.96$ & $280.25 \pm 175.96$ & 0.156 \\
\hline BUN & $11.1 \pm 3.51$ & $10.84 \pm 3.32$ & $10.31 \pm 2.66$ & 0.245 \\
\hline Creatinine & $0.44 \pm 0.11$ & $0.45 \pm 0.10$ & $0.47 \pm 0.11$ & 0.153 \\
\hline Serum calcium & $10.44 \pm 0.77$ & $10.10 \pm 0.56$ & $10.16 \pm 0.48$ & 0.174 \\
\hline
\end{tabular}


macroscopic haematuria. In a study carried out by Liern et al. (22), haematuria (43\%) was the most common cause of admission. In our study, patients applied to hospital with abdominal pain and UTI and then haematuria as the third complaint. The number of patients who attended with haematuria was determined as $\mathbf{3 0 . 8 \%}$. Haematuria was indicated to regress to $8 \%$ during follow-up and after treatment in the literature. While there was no evident decrease in the number of patients with microscopic haematuria, a significant reduction was observed in the number of patients with macroscopic haematuria in our study. Among reasons for the lack of decrease in the number of patients with microscopic haematuria; continuation of macroscopic haematuria with microscopic haematuria and paying attention to fluid intake following their diagnosis were the primary causes that could be considered. The total rate of patients with haematuria was found as $21.1 \%$ after follow-up. This rate is higher than the rates indicated in the literature. The reason for this is thought to be the fact that the rate of nephrolithiasis in our patients was higher than in previous studies.

The correlation of hypercalciuria with $\mathrm{IH}$ was mentioned previously $(8,11,23,24)$. Irritation created by calcium crystals in bowel is held responsible for enuresis forming in idiopathic hypercalciuria. It was suggested that contraction occurs in the bowel as a consequence of this irritation and relaxation takes place at the bowel exit and in this way, involuntary urination occurs (24). The enuresis complaint was present in 6 patients (11.5\%) in our study. In a study performed in the Tekirdağ region by Yazici et al. (25), the enuresis rate was identified as $7.5 \%$ in all children aged between 7-14 years. However, another study conducted in Giresun found the enuresis rate was $18.2 \%$ for those between $7-11$ years old (26). Though the rate of enuresis in our patients was not different from previous studies explicitly, it leads to the consideration that $\mathrm{IH}$ is a facilitating factor for enuresis since we had older patients and enuresis regressed with $\mathrm{IH}$ treatment in our two patients.

While the nephrolithiasis rate is $40-60 \%$ in adults with $\mathrm{IH}$, stone disease is encountered in children with IH at $25-67 \%(8,9,16,19)$. In our study, nephrolithiasis was determined in $78 \%$ of patients with $\mathrm{IH}$. This rate is a little bit higher than the maximum rate in the literature. Dietary habits, lower numbers of paediatric patients compared to adults in studies carried out in children, ethnic and regional differences can be assumed among the reasons for so many different rates in the literature. In accordance with a study performed by Curhan et al. (27), nephrolithiasis incidence was $69 \%$ in the families of children with $\mathrm{IH}$. Similarly, the rate of patients with nephrolithiasis history in their families was $63 \%$.

Various dietary modifications and available pharmacologic therapies such as increasing fluid and low salt intake, thiazide diuretics, and citrate affected the reduction in urinary calcium excretion and/or urinary supersaturation (28). Thiazide diuretics induce passive paracellular calcium reabsorption in the proximal tubule via volume contraction (29). Citrate is another treatment in paediatric patients with $\mathrm{IH}$. Citrate binds to urinary calcium and forms soluble calcium-citrate complexes. In this way, the risk of nephrolithiasis decreases in patients with $\mathrm{IH}$. Various preparations containing citrate are available such as potassium citrate or potassium-magnesium citrate. Long-term use of potassium citrate also increases BMD preventing acid-related bone resorption (30). However, patients may be predisposed to develop calcium-phosphate stones due to the elevation in urine $\mathrm{pH}$ (28). Therefore, these patients should be followed with urine $\mathrm{pH}$. Our patients usually were given a low salt diet, hydrochlorothiazide, potassium or potassium-magnesium citrate treatment while monitoring urine $\mathrm{pH}$.

In studies performed in patients with $\mathrm{IH}, 24 \mathrm{~h}$ urinary calcium excretion rate was over $4 \mathrm{mg} / \mathrm{kg} /$ day initially whereas these values regressed to normal during follow-up. In a study involving 472 patients carried out by Penido et al. (31), $24 \mathrm{~h}$ calcium excretion in urine was $6.67 \mathrm{mg} / \mathrm{kg} /$ day at the time of their admission, but this value reduced to $2.28 \mathrm{mg} /$ $\mathrm{kg} /$ day after 10 year-follow-up. In a study including 176 patients with IH by Polito et al. (32), while $24 \mathrm{~h}$ urinary calcium excretion rate was $6.1 \mathrm{mg} / \mathrm{kg} /$ day at the time of admission, it decreased to $4 \mathrm{mg} / \mathrm{kg} / \mathrm{day}$ during follow-up. In a study carried out by Acar et al. (33) in Turkey, $24 \mathrm{~h}$ urinary calcium excretion rate was $5.8 \mathrm{mg} / \mathrm{kg} /$ day at the time of admission whereas this rate diminished to $1.1 \mathrm{mg} / \mathrm{kg} /$ day after followup. Similarly, $24 \mathrm{~h}$ calcium excretion rate in urine decreased from $6.55 \mathrm{mg} / \mathrm{kg} /$ day on average to 3.53 $\mathrm{mg} / \mathrm{kg} /$ day in our study.

In most studies performed, no significant difference was determined in serum calcium values, 
kidney function tests (BUN, creatinine), PTH, sodium bicarbonate, ALP, urinary $\mathrm{PH}$ and urine density. The changes in these values were not significant in our study. There was a significant reduction in the $25-\mathrm{OH}$ vitamin D level in our study after treatment. However, no correlation was established between vitamin $D$ decrease and $24 \mathrm{~h}$ urinary calcium excretion.

Two important complications of $\mathrm{IH}$ are renal stone and bone loss. In $40-50 \%$ of patients with recurrent renal stone, there was $\mathrm{IH}$ and it is the most common metabolic abnormality $(34,35)$. Moreover, there is $\mathrm{IH}$ disease at rates of $35-40 \%$ in the first- and seconddegree relatives of patients with $\mathrm{IH}$ and renal stone (36). The prevalence is $5-10 \%$ in the general population with no stone and among first degree relatives $(37,38)$. In the present study, there was nephrolithiasis in 41 patients $(78.8 \%)$ and the stones in question were reported to continue in 29 cases (70\%) during followup. In addition, stone developed in 3 patients who did not have any initially.

The second most important complication of $\mathrm{IH}$ is reduction in bone density depending on elevating bone resorption and increased fracture risk $(39,40)$. This correlation was observed in both genders and adult ages. Although there are a limited number of studies in children, most of the results are related to decreases in bone density (particularly vertebra in adults) (41). The patients in our study were followed up for 8 years as the longest period and BMD was evaluated in patients followed-up for more than 5 years and it was found to be normal.

There are a limited number of studies comparing height and weight percentiles of patients with $\mathrm{IH}$ at the time of admission and during follow-up. In a study performed by Cervera et al. (42), while they stated that there was a growth retardation in $8 \%$ of patients, nearly ten years after this study García-Nieto et al. (43) indicated this rate was $2.7 \%$. There were 7 patients with weight percentile below 3 at the time of admission in our study (13.4\%), whereas the number of these patients reduced to one (1.9\%) during followup. There was no height percentile difference. The improvement in the weight percentile of patients was probably dependent on favourable diet practices and reduction in UTI rates. On the other hand, Polito et al. (32) stated that the obesity rate was $4.7 \%$ in patients with $\mathrm{IH}$. There was only one patient with weight percentile over 97 in this study.

\section{Conclusion}

IH should be suspected in patients with abdominal pain, haematuria and UTI history. IH is commonly accompanied by nephrolithiasis and therefore it is appropriate that patients should be evaluated with intermittent imaging. Regression occurs in urinary calcium levels and often in clinical complaints with suitable treatment.

\section{Ethics}

Ethics Committee Approval: The study was begun after receiving the approval of the Ethics Committee of the Dokuz Eylül University (decision no: 2013/1705, date: 02/05/2013).

Informed Consent: Informed consent was obtained from parents or legal guardians before enrollment in the study.

Peer-review: Externally peer-reviewed.

\section{Authorship Contributions}

Concept: A.K., M.T.B., Design: A.S., Supervision: M.A.T., S.K., Data Collection or Processing: M.T.B., A.K., Analysis or Interpretation: M.A.T., A.K., Materials: D.Ö., Literature Search: A.K., Writing: A.K., M.T.B.

Conflict of Interest: No conflict of interest was declared by the authors.

Financial Disclosure: The authors declared that this study received no financial support.

\section{References}

1. Albright F, Henneman P, Benedict PH, Forbes AP. Idiopathic hypercalciuria: a preliminary report. Proc R Soc Med 1953; 46: 1077-81.

2. Mir S, Serdaroglu E. Quantification of hypercalciuria with the urine calcium osmolality ratio in children. Pediatr Nephrol 2005; 20: $1562-5$.

3. Moore ES, Coe FL, McMann BJ, Favus MJ. Idiopathic hypercalciuria in children: prevalence and metabolic characteristics. J Pediatr 1978; 92: 906-10.

4. Stoller ML. Urinary Stone Disease. In: Tanagho EA, McAninch JW, editors. Smith's General Urology. 16th ed. USA: McGrawHillCompanies; 2004. p. 259-62.

5. Ryan LE, Ing SW. Idiopathic hypercalciuria: Can we prevent stones and protect bones? Cleve Clin J Med 2018; 85: 47-54.

6. Flocks RH. Calcium urolithiasis: the role of calcium metabolism in the pathogenesis and treatment of calcium urolithiasis. J Urol 1940; 43: 214.

7. Coe FL, Favus MJ, Crockett T, Strauss AL, Parks JH, Porat A, et al. Effects of low calcium diet on urine calcium excretion, parathyroid function and serum 1,25(OH)2D3 levels in patients with idiopathic hypercalciuria and in normal subjects. Am J Med 1982; 72: 25-32. 
8. Penido MG, Diniz JS, Moreira ML, Tupinambá AL, França $A$, Andrade $\mathrm{BH}$, et al. Idiopathic hypercalciuria: presentation of 471 cases. J Pediatr (Rio J) 2001; 77: 101-4.

9. Vachvanichsanong $\mathrm{P}$, Malagon M, Moore ES. Urinary tract infection in children associated with idiopathic hypercalciuria. Scand J Urol Nephrol 2001; 35: 112-6.

10. Tabel Y, Mir S. The long-term outcomes of idiopathic hypercalciuria in children. J Pediatr Urol 2006; 2: 453-8.

11. Esfahani ST, Madani A, Siadati AA, Nabavi M. Prevalence and symptoms of idiopathic hypercalciuria in primary school children of Tehran. Iran J Pediatr 2007; 17: 353-8.

12. Vezzoli G, Soldati L, Gambaro G. Hypercalciuria revisited: one or many conditions?. Pediatr Nephrol 2008; 23: 503-6.

13. Abhishek KJ, Mandhani A, Srivastava A, Kapoor R, Ansari MS. Pediatric urolithiasis: Experience from a tertiary referral center. J Pediatr Urol 2013; 9: 825-30.

14. Winberg J, Andersen HJ, Bergstöm T, Jacobsson B, Larson $H$, Lincoln K. Epidemiology of symptomatic urinary tract infection in childhood. Acta Paediatr Scand Suppl 1974; 1-20.

15. Fallahzadeh MK, Fallahzadeh MH, Mowla A, Derakhshan A. Hypercalciuria in children with urinary tract symptoms. Saudi J Kidney Dis Transpl 2010; 21: 673-7.

16. Biyikli NK, Alpay H, Guran T. Hypercalciuria and recurrent urinary tract infections: incidence and symptoms in children over 5 years of age. Pediatr Nephrol 2005; 20: 1435-8.

17. Stojanović VD, Milosević BO, Djapić MB, Bubalo JD. Idiopathic hypercalciuria associated with urinary tract infection in children. Pediatr Nephrol 2007; 22: 1291-5.

18. Akil I, Kavukçu S, Inan S, Yilmaz O, Atilla P, Işlekel H, et al. Evaluation of histologic changes in the urinary tract of hypercalciuric rats. Pediatr Nephrol 2006; 21: 1681-9.

19. López MM, Castillo LA, Chávez JB, Ramones C. Hypercalciuria and recurrent urinary tract infection in Venezuelan children. Pediatr Nephrol 1999; 13: 433-7.

20. Yılmaz S, Özçakar ZB, Kurt Şükür ED, Burcu Bulum, Aslı Kavaz, Atilla $\mathrm{H}$ Elhan, et al. Vesicoureteral Reflux and Renal Scarring Risk in Children after the First Febrile Urinary Tract Infection. Nephron 2016; 132: 175-80.

21. Lieske JC, Leonard R, Toback FG. Adhesion of calcium oxalate monohydrate crystals to renal epithelial cells is inhibited by specific anions. Am J Physiol 1995; 268: 604-12.

22. Liern $M$, Bohorquez M, Vallejo $G$. Treatment of idiopathic hypercalciuria and its impact on associated diseases. Arch Argent Pediatr 2013; 111: 110-4.

23. Nicolaidou P, Nyktari G, Georgouli H, Athanassaki K, Garoufi A, Papadimitriou $A$, et al. Atrial natriuretic peptide in children with idiopathic hypercalciuria. Pediatr Nephrol. 2000; 14: 853-5.

24. Valenti G, Laera A, Gouraud S, Pace G, Aceto G, Penza R, et al. Low-calcium diet in hypercalciuric enuretic children symptoms restores AQP2 excretion and improves clinical symptoms. Am J Physiol Renal Physiol 2002; 283: 895-903.

25. Yazici CM, Nalbantoglu B, Topcu B, Dogan C. Prevalence of nocturnal enuresis and associated factors in schoolchildren in Western Turkey. Can J Urol 2012; 19: 6383-8.
26. Üstüner Top F, Küçük Alemdar D. Gümüşhane University Journal of Health Sciences 2014; 3: 991-1004.

27. Curhan GC, Willett WC, Rimm EB, Stampfer MJ. Family history and risk of kidney stones. J Am Soc Nephrol 1997; 8: 1568-73.

28. Lau KK, Butani L. Treatment strategies for pediatric idiopathic hypercalciuria. Front Biosci (Elite Ed) 2009; 1: 299-305.

29. Mensenkamp AR, Hoenderop JG, Bindels RJ. Recent advances in renal tubular calcium reabsorption. Curr Opin Nephrol Hypertens 2006; 15: 524-9.

30. Vescini F, Buffa A, La Manna G, Ciavatti A, Rizzoli E, Bottura A, et al. Long-term potassium citrate therapy and bone mineral density in idiopathic calcium stone formers. J Endocrinol Invest 2005; 28: 218-22.

31. Penido MG, Diniz JS, Moreira ML, Tupinambá AL, França A, Andrade $\mathrm{BH}$, et al. Hipercalciúria idiopática: apresentação de 471 casos [Idiopathic hypercalciuria: presentation of 471 cases]. J Pediatr (Rio J) 2001; 77: 101-4.

32. Polito C, La Manna A, Nappi B, Villani J, Di Toro R. Idiopathic hypercalciuria and hyperuricosuria: family prevalence of nephrolithiasis. Pediatr Nephrol 2000; 14: 1102-4.

33. Acar B, Inci Arikan F, Emeksiz S, Dallar Y. Risk factors for nephrolithiasis in children. World J Urol 2008; 26: 627-30.

34. Coe FL. Treated and untreated recurrent calcium nephrolithiasis in patients with idiopathic hypercalciuria, hyperuricosuria, or no metabolic disorder. Ann Intern Med 1977; 87: 404-10.

35. Lemann J Jr. Pathogenesis of idiopathic hypercalciuria and nephrolithiasis. In: Coe FL, Favus MJ, editors. Disorders of Bone and Mineral Metabolism. New York: Raven Press, 1992: 685-706.

36. Coe FL, Parks JH, Moore ES. Familial idiopathic hypercalciuria. N Engl J Med 1979; 300: 337-40.

37. Giannini S, Nobile M, Dalle Carbonare L, Lodetti MG, Sella S, Vittadello $G$, et al. Hypercalciuria is a common and important finding in postmenopausal women with osteoporosis. Eur J Endocrinol 2003; 149: 209-13.

38. Tannenbaum C, Clark J, Schwartzman K, Wallenstein S, Lapinski $R$, Meier $D$, et al. Yield of laboratory testing to identify secondary contributors to osteoporosis in otherwise healthy women. J Clin Endocrinol Metab 2002; 87: 4431-7.

39. García-Nieto V, Navarro JF, Monge M, García-Rodríguez VE. Bone mineral density in girls and their mothers with idiopathic hypercalciuria. Nephron Clin Pract 2003; 94: 89-93.

40. Penido MG, Lima EM, Marino VS, Tupinambá AL, França A, Souto MF. Bone alterations in children with idiopathic hypercalciuria at the time of diagnosis. Pediatr Nephrol 2003; 18: 133-9.

41. Moreira Guimarães Penido MG, de Sousa Tavares M. Bone disease in pediatric idiopathic hypercalciuria. World J Nephrol 2012; 1: 54-62.

42. Cervera A, Corral MJ, Gómez Campdera FJ, De Lecea AM, Luque A, López Gómez JM. Idiopathic hypercalciuria in children. Classification, clinical manifestations and outcome. Acta Paediatr Scand 1987; 76: 271-8.

43. García-Nieto V, Ferrández C, Monge M, de Sequera M, Rodrigo MD. Bone mineral density in pediatric patients with idiopathic hypercalciuria. Pediatr Nephrol 1997; 11: 578-83. 